\title{
Antisalmonellal Activities of Extracts, Fractions, Compounds and Semi-synthetic Flavonoid Derivatives from Tristemma hirtum P. Beauv (Melastomataceae)
}

\author{
Joseph Nandjou Kenfack ${ }^{1}$, David Tsafack Ngoudjou ${ }^{2}$, Beaudelaire Kemvoufo Ponou, \\ Jonas Kühlborn ${ }^{3}$, Borice Tapondjou Tsafack ${ }^{1}$, Rémy Bertrand Teponno ${ }^{1}$, Till Opatz ${ }^{3}$, \\ Luciano Barboni ${ }^{4}$, Donatien Gatsing ${ }^{2}$, Léon Azefack Tapondjou ${ }^{1}{ }^{*}$ \\ ${ }^{1}$ Research Unit of Environmental and Applied Chemistry, Department of Chemistry, Faculty of Science, University of Dschang, Dschang, \\ Cameroon \\ ${ }^{2}$ Research Unit of Microbiology and Antimicrobial Substances, Department of Biochemistry, Faculty of Science, University of Dschang, \\ Dschang, Cameroon \\ ${ }^{3}$ Johannes Gutenberg University Mainz, Institute of Organic Chemistry, Mainz, Germany \\ ${ }^{4}$ School of Science and Technology, Chemistry Division, University of Camerino, Camerino, Italy
}

Email address:

tapondjou2001@yahoo.fr (L. A. Tapondjou)

${ }^{*}$ Corresponding author

\section{To cite this article:}

Joseph Nandjou Kenfack, David Tsafack Ngoudjou, Beaudelaire Kemvoufo Ponou, Jonas Kühlborn, Borice Tapondjou Tsafack, Rémy Bertrand Teponno, Till Opatz, Luciano Barboni, Donatien Gatsing, Léon Azefack Tapondjou. Antisalmonellal Activities of Extracts, Fractions, Compounds and Semi-synthetic Flavonoid Derivatives from Tristemma hirtum P. Beauv (Melastomataceae). Science Journal of Chemistry. Vol. 8, No. 3, 2020, pp. 48-58. doi: 10.11648/j.sjc.20200803.12

Received: March 31, 2020; Accepted: April 24, 2020; Published: May 27, 2020

\begin{abstract}
The development and spread of resistance to currently available antibiotics is a major drawback in the treatment of microbial infections. Salmonellosis for example remains among the most common cause of morbidity and mortality in developing countries. This study aimed to evaluate the antisalmonellal potential of extracts, fractions, isolated compounds and semi-synthetic flavonoids from Tristemma hirtum P. Beauv. Bioguided fractionation by column chromatography of the EtOAc and $n-\mathrm{BuOH}$ fractions led to the isolation of eleven compounds including two new esterified glucuronide flavonoids namely: luteolin-3'-O- $\beta$ - - -glucuronopyranosylbutyl ester (1), a mixture of compound 1 and quercetin-3- $O-\beta{ }_{-\mathrm{D}}$-glucuronopyranosylbutyl ester (2). Chemical transformation mainly based on the prenylation of 6-hydroxyapigenin-7- $O-\beta$ - - -glucopyranoside (5) afforded four new semi-synthetic flavonoid derivatives namely: 6,4 '- $O$-diprenylapigenin-7- $O-\beta$ - - -glucopyranoside (5a), $8-C$ prenyl-6, 4'-O-diprenylapigenin-7- $O-\beta$ - ${ }_{\mathrm{D}}$-glucopyranoside (5b), 8-C-prenyl-4'-O-prenylapigenin-7- $O-\beta$ - $\mathrm{D}$-glucopyranoside (5c), 4'-O-prenylapigenin-7-O- $\beta$ - - - glucopyranoside $(5 \mathrm{~d})$. The chemical structures of these compounds were assigned using NMR techniques, mass spectrometry and by comparison of their data with reported ones. The antisalmonellal activity was assessed by determining the Minimum Inhibitory Concentration (MIC) and Minimum Bactericidal Concentration (MBC) using serial microdilution methods. The results showed that the $\mathrm{MeOH}$ extract and EtOAc fraction were active against all the bacteria tested with MICs ranging from 24 to $1536 \mu \mathrm{g} / \mathrm{mL}$. Seven isolated compounds and three semi-synthetic compounds tested showed MIC values ranging from 16 to $256 \mu \mathrm{g} / \mathrm{mL}$. Compounds $1,3,5 \mathrm{a}, 5 \mathrm{c}$ and 11 displayed the most potent antisalmonellal properties but were generally less potent than those of reference drugs. The activity of extracts and isolated compounds could be used as the starting point for the development of alternative phytodrugs against salmonellosis.
\end{abstract}

Keywords: Tristemma hirtum, Phytochemistry, Structure Elucidation, Semi-synthetic Flavonoid Derivatives, Antisalmonellal Activity, Structure-Activity Relationships 


\section{Introduction}

According to the World Health Organization, there is an estimated 22 million cases of typhoid fever causing 216500 deaths each year in the world [1]. Despite the multiple use of antibiotics couple to the advanced research and development of new products, typhoid and paratyphoid remain important problems in developing countries, particularly in Asia and in sub-Saharan Africa [2-4]. Also, the non-respect of medical prescriptions and the practice of auto medication cause resistance to common antibiotics including third generation quinolones [5]. Salmonella or bacteria causing salmonellosis are intracellular Gram-negative pathogens. These genera include Salmonella typhi, Salmonella paratyphi A, Salmonella paratyphi B and Salmonella typhimurium [6, 7]. The global emergence of multi-drug resistant bacteria invokes a necessity to identify new antibacterial therapy. Thus, secondary metabolites from plant origin appear to be an alternative source of new efficient and active compounds.

The Melastomataceae family is the seventh largest flowering plants and is known as an important source of terpenoids, phenolic compounds, quinones, lignans, tannins as well as their glycoside derivatives [8, 9] that may be responsible for their traditional medicinal applications [10]. Previous studies carried out on extracts of some plants belonging to Melastomataceae family as Dissotis perkinsiae, Dissotis thollonii and Tristemma mauritianum proved their anti-oxidant and antimicrobial activities [9, 11, 12 ]. As a rare species, Tristemma hirtum is a herb or small forest bush of $1.25 \mathrm{~m}$ high, which grows in marsh usually found in tropical Africa, especially in Ivory Coast, Equatorial Guinea and Cameroon [13]. It is widely found in the West Region of Cameroon where it is used in folk medicine, associated with other plants for the treatment of hemorrhoids, reproductive problems, skin diseases and typhoid fever [14, 15]. Previously, researchers have reported antibacterial activities of Tristemma hirtum extracts [16]. As part of our ongoing phytochemical studies of medicinal plants growing in Cameroon, we have previously reported the isolation and characterization of ten compounds including flavonoids, terpenoids, glycerol derivatives and hydrolysable tannins from some fractions of the methanol extract from Tristemma hirtum [17]. In continuation, this work aimed to isolate compounds from T. hirtum capable to inhibit Salmonella bacteria supporting its traditional usage against typhoid fever. The chemical prenylation of 6-hydroxyapigenin-7-O- $\beta{ }_{-}{ }^{-}$ glucopyranoside afforded four new semi-synthetic derivatives that were also evaluated for their antisalmonellal activity.

\section{Materials and Methods}

\subsection{General Experimental Procedures}

Optical rotations were determined using a JASCO digital polarimeter (Model DIP-3600). ${ }^{1} \mathrm{H}$ NMR, ${ }^{13} \mathrm{C}$ NMR, COSY, HMQC and HMBC spectra were performed in deuterated solvents on a Bruker DRX 500 Spectrometer at $500 \mathrm{MHz}$ and on a Bruker AVANCE III 600 spectrometer (Bruker, Germany) at $600 \mathrm{MHz}$. All chemical shifts $(\delta)$ are given in ppm with reference to tetramethylsilane (TMS) as internal standard or by using the remaining protonated solvent as an internal standard and the coupling constants $(J)$ are in Hz. High resolution mass spectra were obtained with a QTOF Compact Spectrometer (Bruker, Germany) equipped with a HRESI source. The spectrometer was operated in positive and negative modes (mass range: 50-1500, with a scan rate of $1.00 \mathrm{~Hz}$ ) with automatic gain control to provide high-accuracy mass measurements within 0.4 ppm deviation using Na Formate as calibrant. Column chromatography was performed using 70230 mesh and 230-400 mesh silica gel 60 (Merck) and sephadex LH-20. TLC was carried out on precoated silica gel $60 \mathrm{~F}_{254}$ (Merck) plates and spots were visualized by a UV lamp multiband UV-254/365 nm (Model UVGL-58 Upland CA 91786, USA) and by spraying with $50 \% \mathrm{H}_{2} \mathrm{SO}_{4}$ and heating for $10 \mathrm{~min}$ at $110^{\circ} \mathrm{C}$.

\subsection{Plant Material}

The aerial parts of Tristemma hirtum P. Beauv. were collected in Bangang, Bamboutos Division, Western Region of Cameroon in January 2015. The plant material was identified by $\mathrm{Mr}$ Flubert TADJOUTEU, botanist at the Cameroon National Herbarium, Yaoundé, where a voucher specimen was kept (reference number (33937/HNC)).

\subsubsection{Extraction and Bioactivity-guided Fractionation of Tristemma Hirtum}

Dried aerial parts $(3 \mathrm{~kg})$ were extracted with $\mathrm{MeOH}$ at room temperature for 3 days, and the extract was concentrated to dryness under reduced pressure to yield a dark crude extract $(543.3 \mathrm{~g})$. After a preliminary test that revealed the antisalmonellal activity of the methanol extract, $519 \mathrm{~g}$ were suspended in distilled water $(500 \mathrm{~mL})$ and successively extracted with EtOAc and $n$-BuOH. The organic phases were concentrated to dryness under reduced pressure, yielding $130 \mathrm{~g}$ and $136 \mathrm{~g}$ of EtOAc and $n$-BuOH extract, respectively as well as aqueous residual fraction. The assessment of the antisalmonellal activities of the fractions showed the EtOAc fraction to be more active than the $n$ $\mathrm{BuOH}$, while no activity was observed for the aqueous residual fraction.

Part of the EtOAc fraction (100 g) was fractionated on a silica gel column chromatography using a gradient of EtOAc in $n$-hexane and then a gradient of $\mathrm{MeOH}$ in EtOAc, to give six main sub-fractions F1-F6. F3 (15 g) was chromatographed on silica gel column eluted with the mixture of $n$-hexane-EtOAc (40: 60) to afford four subfractions (F3a-F3d). Sephadex LH-20 gel filtration of the sub-fraction F3d (200 mg) using $\mathrm{CH}_{2} \mathrm{Cl}_{2}-\mathrm{MeOH}$ (50: 50) followed by purification on silica gel column using a mixture of $n$-hexane-EtOAc (40:60) yielded compounds 6 (30 mg), 7 $(45 \mathrm{mg})$ and $3(21 \mathrm{mg})$. F4 (11 g) was subjected to sephadex LH-20 gel column chromatography to obtain three subfractions (F4a-F4c). Sub-fraction F4c (350 mg) was purified on the reverse phase silica (RP-18) column chromatography 
eluting with a mixture of $\mathrm{MeOH}-\mathrm{H}_{2} \mathrm{O}(30: 70)$ to yield compound $9(140.8 \mathrm{mg})$. A portion of F6 (6.5 g) eluted with EtOAc-MeOH (70: 30) was chromatographed on silica gel column using the mixture of EtOAc-MeOH- $\mathrm{H}_{2} \mathrm{O}$ (90: 10: 5) as eluent to afford three sub-fractions (F6a-F6c). Repeated sephadex LH-20 gel column chromatography of sub-fraction F6a (180 mg) with $\mathrm{CH}_{2} \mathrm{Cl}_{2}-\mathrm{MeOH}$ (50: 50) followed by successive purification on silica gel leading to the isolation of $1(17 \mathrm{mg})$ and $2(8 \mathrm{mg})$. From sub-fractions F6b $(120 \mathrm{mg})$ a mixture of compounds $8 \mathrm{a}$ and $8 \mathrm{~b}(8 \mathrm{mg})$ was obtained after purification over a silica gel column eluted with EtOAc$\mathrm{MeOH}-\mathrm{H}_{2} \mathrm{O}$ (95: 5: 2).

Part of the $n$-BuOH fraction (100 g) was subjected to column chromatography over silica gel eluted with increasing polarity of EtOAc- $\mathrm{MeOH}$ to yield five main subfractions (FA-FE). Subfraction FC (EtOAc-MeOH 80: 20) $(8.8 \mathrm{~g})$ was subjected to sephadex LH-20 gel column chromatography to obtain compound $5(620 \mathrm{mg})$ as previously described [17] upon recrystallization from $\mathrm{MeOH}$ fraction FB (4.2 g) eluted with the mixture EtOAc-MeOH (90: 10) was repeatedly subjected to sephadex LH-20 gel column chromatography eluted with $\mathrm{MeOH}$ followed by successive purification on silica gel leading to the isolation of compound 4 (10 mg). Subfraction FD (3.7 g) was subjected to sephadex LH-20 gel column eluted with $\mathrm{MeOH}$ to yield four sub-fractions (D1-D4). From sub-fraction D2 (1.2 g) compound 11 (300 mg) was obtained after repeated RP-18 silica gel column chromatography eluted with increasing polarity of $\mathrm{MeOH}-\mathrm{H}_{2} \mathrm{O}$ [(80: 20), (70: 30), (60: 40), (50: 50)]. From sub-fraction D4, compound 10 (95 mg) was obtained upon recrystallization with $\mathrm{MeOH}$.

\subsubsection{Preparation of Semi-synthetic Derivatives (5a-5d) from 6-Hydroxyapigenin-7-O- $\beta-{ }_{-}-$Glucopyranoside} (5)

A portion $200 \mathrm{mg}$ 6-hydroxyapigenin-7- $O-\beta-\mathrm{D}^{-}$ glucopyranoside (5) $(0.446 \mathrm{~mol})$ was dissolved in $30 \mathrm{~mL}$ acetone and $64.8 \mathrm{mg} \mathrm{K} \mathrm{CO}_{3}(0.469 \mathrm{~mol})$ and $54.1 \mu \mathrm{L}$ prenyl bromide $(0.459 \mathrm{~mol})$ were added successively to the resulting solution. The mixture was magnetically stirred at room temperature $\left(25^{\circ} \mathrm{C}\right)$ and monitored by TLC until complete disappearance of the starting material (12 hours). Afterwards, distilled water was added and the mixture was extracted with $n$ - $\mathrm{BuOH}$. The obtained organic phase was washed with water, dried over anhydrous $\mathrm{Na}_{2} \mathrm{SO}_{4}$ and the solvent was evaporated under vacuum. The obtained mixture was chromatographed over silica gel using an isocratic solvent system of $n$-hexaneEtOAc (60:40) as the eluent and then purified over multiple step of sephadex LH-20 gel column chromatography with $\mathrm{MeOH}$ as the eluent to yield four compounds $54.1 \mathrm{mg}$ of $5 \mathrm{a}$ (20.75\%), $36.8 \mathrm{mg}$ of $5 \mathrm{~b}(12.64 \%), 44.5 \mathrm{mg}$ of $5 \mathrm{c}(17.06 \%)$ and $25.7 \mathrm{mg}$ of $5 \mathrm{~d}(11.15 \%)$.

\subsection{Antibacterial Activity}

\subsubsection{Bacteria Used and Culture Media}

Microorganisms used for antimicrobial activities included four isolates namely Salmonella typhi, Salmonella paratyphi
A, Salmonella paratyphi B and Salmonella typhimurium. These isolates were obtained from the Medical Bacteriology Laboratory of the Centre Pasteur, Yaoundé, Cameroon. One strain of Salmonella typhi ATCC6539 obtained from American Type Culture Collection was used as reference strain. They were maintained in Mueller Hinton Broth (MHB)/Glycerol $(1: 1)$ at $-20^{\circ} \mathrm{C}$ and subcultured on fresh appropriate agar plates $24 \mathrm{~h}$ prior to any antimicrobial test. Culture media used were Salmonella-Shigella Agar (SSA) for activation and maintenance of Salmonella strain/isolates and Mueller Hinton Broth (MHB) for sensibility test (MICs) and (MBCs).

\subsubsection{In vitro Antisalmonellal Assay}

The MICs of extracts, fractions and isolated compounds were determined using serial microdilution using rapid 2-(4iodophenyl)-3-(4-nitrophenyl)-5-phenyl-2H-tetrazolium

(INT) (Sigma Aldrich, St Quentin Fallavier, France) colorimetric assay. The samples were carried out in 96-micro well sterile plates as previously described [18]. For this, the test extracts/fractions were dissolved in dimethyl sulfoxide (DMSO)/Mueller Hinton Broth (MHB) $(\mathrm{v} / \mathrm{v}, 5 \%)$. This solution was then serially introduced in the different wells of the microplate, which contains $100 \mu \mathrm{L} /$ well of MHB. One hundred microliters of inoculum $\left(1.5 \times 10^{6} \mathrm{CFU} / \mathrm{mL}\right)$ prepared in MHB were added to the respective wells. The plates were covered with a sterile plate sealer and incubated at $37^{\circ} \mathrm{C}$ for $18 \mathrm{~h}$. Wells containing MHB, $100 \mu \mathrm{L}$ of bacterial suspensions and DMSO at a final concentration of $2.5 \%$ served as a negative control. Ciprofloxacin was used as reference antibiotic. The MICs of samples were detected after $18 \mathrm{~h}$ of incubation at room temperature $\left(25^{\circ} \mathrm{C}\right)$, following addition of $40 \mu \mathrm{L}$ of $0.2 \mathrm{mg} / \mathrm{mL}$ INT and incubation at $37^{\circ} \mathrm{C}$ for $30 \mathrm{~min}$ [19]. Viable bacteria reduced the yellow color of INT into pink. The MIC was defined as the lowest sample concentration that prevented this colour change and exhibited inhibition of microbial growth. The MBCs were determined by adding $50 \mu \mathrm{L}$ aliquots of the preparations (without INT), which did not show any visible colour change after incubation during MIC assays, into 150 $\mu \mathrm{L}$ of fresh Mueller Hinton broth. These preparations were further incubated at $37^{\circ} \mathrm{C}$ for $48 \mathrm{~h}$ and bacterial growth was revealed by the addition of INT as above. The lowest concentration at which no visible colour change was observed was considered as the MBC. These tests were performed in triplicates at three different occasions.

\section{Results and Discussion}

\subsection{Chemical Analysis}

The dry aerial parts of $T$. hirtum ( $3 \mathrm{~kg}$ ) were extracted with methanol. Part of the crude extract $(519 \mathrm{~g})$ was suspended in water and successively extracted with EtOAc and $n-\mathrm{BuOH}$ to yield $130 \mathrm{~g}$ and $136 \mathrm{~g}$ of EtOAc and $n$-BuOH extracts, respectively. Parts of EtOAc and $n$-BuOH fractions were subjected to column chromatography over silica gel and sephadex LH-20 gel to yield eleven secondary metabolites 
(Figure 1). Known compounds were identified as: mixture of arjunolic acid-28- $\beta-{ }_{-}$-glucopyranosyl ester (Arjunglucoside II) (8a) and asiatic acid-28- $\beta$ - ${ }_{\mathrm{D}}$-glucopyranosyl ester (Quadranoside IV) (8b) [20], $\beta$-sitosterol (6), oleanolic acid (7), ellagic acid (10), casuarinine (11) [11], luteolin (3) [21],<smiles>[Y10]c1cc(-c2oc3cc([R20])c([R4])c(O)c3c(=O)c2[R])ccc1O</smiles>

1: $\mathrm{R}^{1}=\mathrm{R}^{2}=\mathrm{R}^{3}=\mathrm{H}, \mathrm{R}^{4}=O-\beta$ - $\mathrm{D}$-glucuronopyranosylbutylester 2: $\mathrm{R}^{1}=O-\beta$ - -glucuronopyranosylbutylester, $\mathrm{R}^{2}=\mathrm{R}^{3}=\mathrm{H}, \mathrm{R}^{4}=\mathrm{OH}$ 3: $\mathrm{R}^{1}=\mathrm{R}^{2}=\mathrm{R}^{3}=\mathrm{H}, \mathrm{R}^{4}=\mathrm{OH}$

4: $\mathrm{R}^{1}=\mathrm{OH}, \mathrm{R}^{2}=\mathrm{R}^{3}=\mathrm{H}, \mathrm{R}^{4}=\beta$ - -glucopyranosyl

5: $\mathrm{R}^{1}=\mathrm{H}, \mathrm{R}^{2}=\mathrm{OH}, \mathrm{R}^{3}=\beta$ - $\mathrm{D}$-glucopyranosyl, $\mathrm{R}^{4}=\mathrm{H}$ pterocaryanin $\mathrm{C}(9)$ [22], quercetin-3- $O-\beta$-D-glucopyranoside $_{\text {- }}$ (4) [23] and 6-hydroxyapigenin-7- $O-\beta$ - ${ }_{\mathrm{D}}$-glucopyranoside (5) [17] by spectroscopic analysis and by comparison of their data with those reported in the literature.<smiles>CC[C@H](CC[C@H](C)C1CCC2C3CC=C4C[C@@H](O)CC(C)[C@]4(C)C3CC[C@@]21C)C(C)C</smiles>

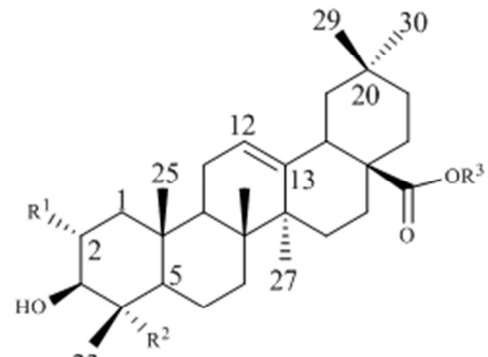

7: $\mathrm{R}^{1} \stackrel{23}{=} \mathrm{H}, \mathrm{R}^{2}=\mathrm{CH}_{3}, \mathrm{R}^{3}=\mathrm{H}$ $8 \mathrm{a}: \mathrm{R}^{1}=\mathrm{OH}, \mathrm{R}^{2}=\mathrm{CH}_{2} \mathrm{OH}, \mathrm{R}^{3}=\beta$-D-glucopyranosyl
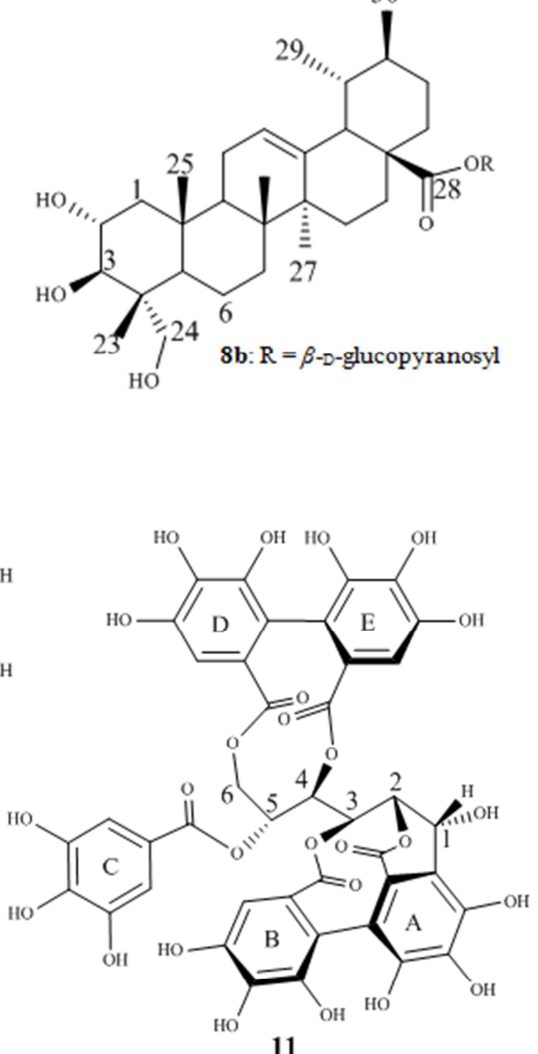

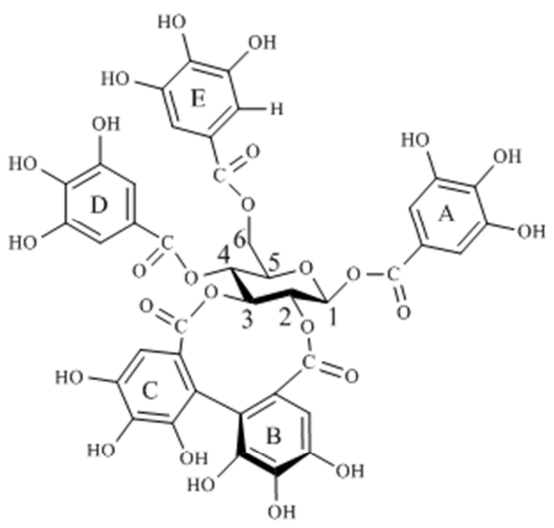

9<smiles>O=c1oc2c(O)c(O)cc3c(=O)oc4c(O)c(O)cc1c4c23</smiles>

11

Figure 1. Structures of compounds isolated from Tristemma hirtum.

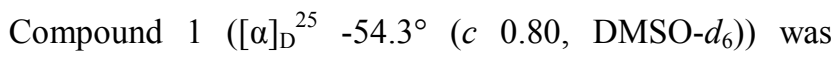
isolated with $\mathrm{MeOH}$ as a yellow amorphous powder. Its molecular formula $\mathrm{C}_{25} \mathrm{H}_{26} \mathrm{O}_{12}$ was suggested by the HRESIMS (positive mode) which exhibited the $[\mathrm{M}+\mathrm{H}]^{+}$adduct at $m / z 519.1546$ (Calcd. for $\mathrm{C}_{25} \mathrm{H}_{27} \mathrm{O}_{12}{ }^{+}:$519.1503). This was confirmed by the HRESI-MS (negative mode) which showed a [M-H] peak at $\mathrm{m} / z 517.1348[\mathrm{M}-\mathrm{H}]^{-}$(Calcd. for $\mathrm{C}_{25} \mathrm{H}_{25} \mathrm{O}_{12}$ : 517.1346) indicating the molecular formula $\mathrm{C}_{25} \mathrm{H}_{26} \mathrm{O}_{12}$ having 13 degrees of unsaturation. The ${ }^{1} \mathrm{H}$ NMR spectrum of compound 1 (DMSO- $d_{6} ; 600 \mathrm{MHz}$, Table 1) showed one deshielded proton signal at $\delta_{\mathrm{H}} 12.96(1 \mathrm{H}, \mathrm{s})$ corresponding to the chelated proton 5-OH. It also exhibited a set of signals at $\delta_{\mathrm{H}} 6.88(1 \mathrm{H}, \mathrm{s}, \mathrm{H}-3), 6.21(1 \mathrm{H}, \mathrm{d}, J=2.1 \mathrm{~Hz}, \mathrm{H}-6), 6.49(1 \mathrm{H}$, $\mathrm{d}, J=2.1 \mathrm{~Hz}, \mathrm{H}-8), 7.67\left(1 \mathrm{H}, \mathrm{d}, J=2.2 \mathrm{~Hz}, \mathrm{H}-2^{\prime}\right), 6.99(1 \mathrm{H}$, $\left.\mathrm{d}, J=8.4 \mathrm{~Hz}, \mathrm{H}-5^{\prime}\right)$ and $7.65\left(1 \mathrm{H}, \mathrm{dd}, J=2.2 ; 8.4 \mathrm{~Hz}, \mathrm{H}-6^{\prime}\right)$. These protons showed correlations in the HSQC spectrum with the carbons at $\delta_{\mathrm{C}} 103.7(\mathrm{C}-3), 99.3(\mathrm{C}-6), 94.5(\mathrm{C}-8)$, $114.0\left(\mathrm{C}-2^{\prime}\right), 117.0\left(\mathrm{C}-5^{\prime}\right)$ and at $\delta_{\mathrm{C}} 122.2\left(\mathrm{C}-6^{\prime}\right)$ respectively, indicating the presence of a 5, 7, 3', 4'-tetrahydroxyflavone (luteolin) moiety in the molecule [21]. The ${ }^{1} \mathrm{H}$ NMR 
spectrum also exhibited an anomeric proton signal at $\delta_{\mathrm{H}} 5.27$ $\left(1 \mathrm{H}, \mathrm{d}, J=7.5 \mathrm{~Hz}, \mathrm{H}-1^{\prime \prime}\right)$ showing HSQC correlation with the corresponding anomeric carbon at $\delta_{\mathrm{C}} 100.8\left(\mathrm{C}-1^{\prime \prime}\right)$. Complete assignment of the protons and carbons of the sugar unit was achieved by analysis of ${ }^{1} \mathrm{H}-{ }^{1} \mathrm{H}$ COSY, HSQC and HMBC spectra. The sugar was identified as a glucuronic acid and this was further confirmed by its quaternary carbonyl carbon (C- $\left.6^{\prime \prime}\right)$ at $\delta_{\mathrm{C}} 169.2$ [24], and the $\beta$ configuration deduced from the coupling constant of $7.5 \mathrm{~Hz}$ [25]. The ${ }_{D}$-configuration of the glucuronyl unit was assumed according to the one most encountered in plant glycosides [26]. Moreover, two oxymethylene protons with acyl induced downfield shifts appearing at $\delta_{\mathrm{H}} 4.05$ and $4.13 \mathrm{ppm}$ showed correlations in the HSQC spectrum with the carbon at $\delta_{\mathrm{C}} 64.8\left(\mathrm{C}-1^{\prime \prime \prime}\right)$. Furthermore, the presence of two signals at $\delta_{\mathrm{H}} 1.51(2 \mathrm{H}, \mathrm{m}$, $\left.\mathrm{H}-2^{\prime \prime \prime}\right)$ and $1.24 \mathrm{ppm}\left(2 \mathrm{H}, \mathrm{q}, J=7.5 \mathrm{~Hz}, \mathrm{H}-3^{\prime \prime \prime}\right)$ of two methylene protons and the terminal methyl group at $\delta_{\mathrm{H}} 0.74$

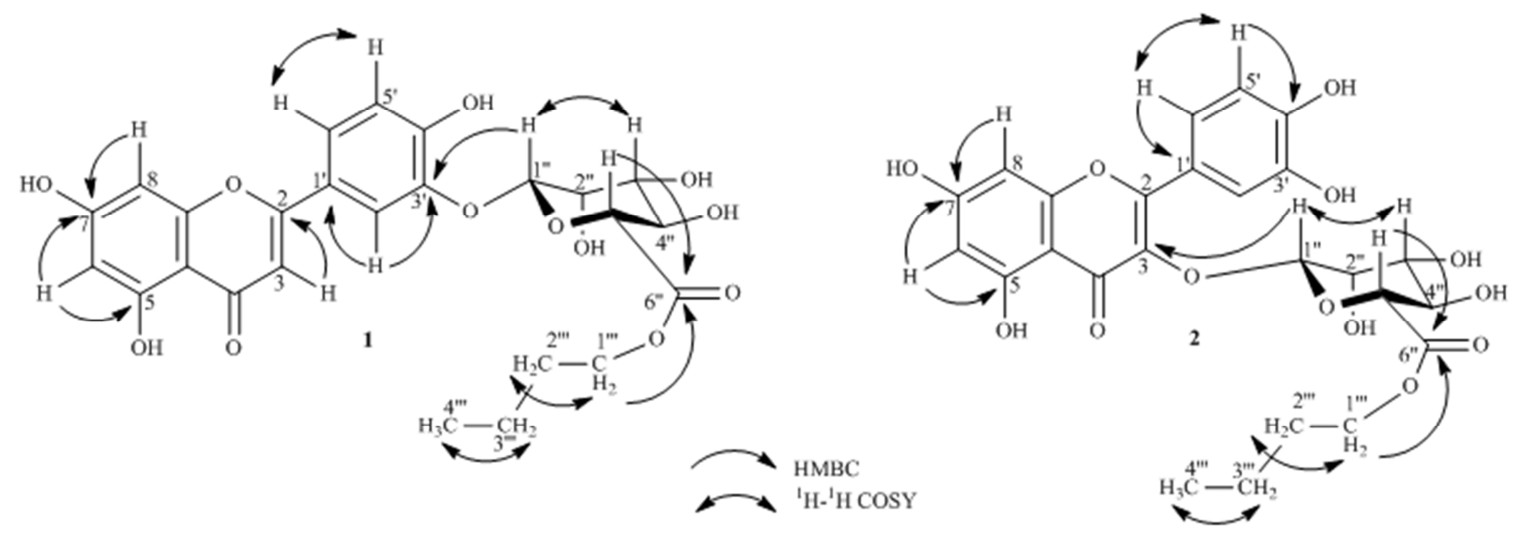

Figure 2. Selected $H M B C$ and ${ }^{l} H-{ }^{l} H C O S Y$ correlations of compounds 1 and 2.

Compound 2 was obtained as a yellow amorphous powder. It appeared as a mixture of two related secondary metabolites despite repeated column chromatographic separation and the apparent homogeneity on TLC. The negative mode HRESIMS showed two pseudomolecular ion peaks at $\mathrm{m} / \mathrm{z} 517.1348$ $\left[\mathrm{M}^{1}-\mathrm{H}\right]^{-}$(Calcd. for $\left.\mathrm{C}_{25} \mathrm{H}_{25} \mathrm{O}_{12}: 517.1346\right)$ and 533.1298 [M ${ }^{2}-$ $\mathrm{H}]^{-}$(Calcd. for $\mathrm{C}_{25} \mathrm{H}_{25} \mathrm{O}_{13}: 533.1295$ ) corresponding to the molecular formula of $\mathrm{C}_{25} \mathrm{H}_{26} \mathrm{O}_{12}$ and $\mathrm{C}_{25} \mathrm{H}_{26} \mathrm{O}_{13}$ of compounds 1 and 2, respectively. This was confirmed by the positive mode HRESI-MS which displayed sodic adduct peaks at $m / z 557.1271\left[\mathrm{M}^{2}+\mathrm{Na}\right]^{+}$(Calcd. for $\mathrm{C}_{25} \mathrm{H}_{26} \mathrm{O}_{13} \mathrm{Na}$ : 557.1271).

The ${ }^{1} \mathrm{H}$ NMR and ${ }^{13} \mathrm{C}$ NMR spectra of 2 (Table 1), revealed that it was a mixture containing compound 1 . In addition to signals attributed to compound 1 , the ${ }^{1} \mathrm{H}$ NMR spectrum showed a set of signals at $\delta_{\mathrm{H}} 6.23(1 \mathrm{H}, \mathrm{d}, J=2.1$ $\mathrm{Hz}, \mathrm{H}-6)$ and $6.42(1 \mathrm{H}, \mathrm{d}, J=2.2 \mathrm{~Hz}, \mathrm{H}-8) \mathrm{ppm}$, giving correlations in the HSQC spectrum with carbons at $\delta_{\mathrm{C}} 98.6$ and $93.3 \mathrm{ppm}$, respectively, characteristic of one flavonoid unit having the C-5 and C-7 dioxygenation patterns [29]. The $\mathrm{ABX}$ spin system due to the signals of aromatic ring protons at $\delta_{\mathrm{H}} 6.86\left(1 \mathrm{H}, \mathrm{d}, J=8.4 \mathrm{~Hz}, \mathrm{H}-5^{\prime}\right), 7.65(1 \mathrm{H}, \mathrm{d}, J=2.2 \mathrm{~Hz}$, $\left.\mathrm{H}-6^{\prime}\right)$ and $7.62\left(1 \mathrm{H}, \mathrm{d}, J=2.2 \mathrm{~Hz}, \mathrm{H}-2^{\prime}\right)$ suggested the presence of a $3^{\prime}, 4^{\prime}, 5$, 7-tetrasubstituted flavone skeleton. Furthermore, a characteristic signal was observed in the ${ }^{13} \mathrm{C}$ $\left(3 \mathrm{H}, \mathrm{t}, J=7.4 \mathrm{~Hz}, \mathrm{H}-4^{\prime \prime \prime}\right)$ indicated the presence of an $O-$ butyl group [27, 28]. The presence of this group was confirmed by four signals on the ${ }^{13} \mathrm{C}$ NMR (DMSO- $d_{6} ; 150$ $\mathrm{MHz}$ ) spectrum at $\delta_{\mathrm{C}} 64.8, \quad 30.5, \quad 18.9,13.9$ ppm corresponding to C-1"', C-2"', C-3"', and C-4"', respectively. The total assignment of protons and carbons of this spin system was achieved by ${ }^{1} \mathrm{H}-{ }^{1} \mathrm{H}$ COSY, HSQC and HMBC correlations. The connectivity of the flavonoid aglycone, glucuronic acid moiety and butyl ester group was determined by $\mathrm{HMBC}$ correlations between the anomeric proton at $\delta_{\mathrm{H}}$ $5.27\left(\mathrm{H}-1^{\prime \prime}\right)$ and carbon $\mathrm{C}-3^{\prime}$ at $\delta_{\mathrm{C}} 145.5$, and also between the oxymethylene protons of the butyl ester group (H-1"'a/ Hb1 '"b) at $\delta_{\mathrm{H}} 4.05 / 4.13 \mathrm{ppm}$ and the glucuronic acid moiety carbonyl C-6" at $\delta_{\mathrm{C}} 169.2 \mathrm{ppm}$ (Figure 2). The structure of 1 was thus concluded to be luteolin-3'-O- $\beta{ }_{-}{ }^{-}$ glucuronopyranosylbutyl ester.

NMR spectrum at $\delta_{\mathrm{C}} 133.9 \mathrm{ppm}$ (Table 1) corresponding to $\mathrm{C}-3$ of the flavonol skeleton [23]. The difference in the molecular weight of 1 and 2 was 16 a. m. u. which indicates the presence of an additional oxygen atom in compound 2 having a quercetin skeleton as the aglycone [29]. The ${ }^{1} \mathrm{H}$ NMR spectrum also showed the anomeric proton signal of an additional sugar unit at $\delta_{\mathrm{H}} 5.31\left(1 \mathrm{H}, \mathrm{d}, J=7.8 \mathrm{~Hz}, \mathrm{H}-1^{\prime \prime}\right)$ which had HSQC correlation with the corresponding anomeric carbon at $\delta_{\mathrm{C}} 102.9 \mathrm{ppm}\left(\mathrm{C}-1^{\prime \prime}\right)$. The complete assignment of the protons and carbons of the glucuronide butyl ester moiety with its carbonyl signal at $\delta_{\mathrm{C}} 168.7\left(\mathrm{C}-6^{\prime \prime}\right)$ and its butyl signals at $\delta_{\mathrm{C}} 64.8\left(\mathrm{C}-1^{\prime \prime \prime}\right), 30.1\left(\mathrm{C}-2^{\prime \prime \prime}\right), 18.5(\mathrm{C}-$ $\left.3^{\prime \prime \prime}\right), 12.5$ (C-4"') was achieved as for compound 1 [27, 28]. The connectivity of the aglycone, glucuronic acid and butyl ester group was also determined by the HMBC correlations between the anomeric proton $\mathrm{H}-1^{\prime \prime \prime}\left(\delta_{\mathrm{H}} 5.31\right)$ and $\mathrm{C}-3\left(\delta_{\mathrm{C}}\right.$ $133.9 \mathrm{ppm})$ of the aglycone, and between the oxymethylene protons of the butyl ester group $\left(\mathrm{H}-1^{\prime \prime \prime}\right)$ at $\delta_{\mathrm{H}} 4.08$ and a carbonyl carbon C-6" of glucuronic acid moiety at $\delta_{\mathrm{C}} 168.7$ (Figure 2). Consequently, the structure of compound 2 was found to be quercetin-3- $O-\beta-{ }_{\mathrm{D}}$-glucuronopyranosylbutyl ester.

In order to verify if compounds 1 and 2 are natural products and not artifacts formed during extraction, comparative TLC was performed and revealed their presence 
in the $\mathrm{MeOH}$ extract. This is in agreement with other $\beta$ - $\mathrm{D}^{-}$ glucuronopyranoside $6 "$-O-butyl ester derivatives previously reported from Araliaceae [30], Aquifoliaceae [31] and Cucurbitaceae [32] plant species as naturally occurring compounds.

Table 1. ${ }^{1} \mathrm{H}$ and ${ }^{13} \mathrm{C}$ NMR data of compounds 1 and 2 [ $\left.\delta(\mathrm{ppm}), J(\mathrm{~Hz})\right]$.

\begin{tabular}{|c|c|c|c|c|}
\hline \multirow{2}{*}{ Position } & \multicolumn{2}{|c|}{ Compound 1* } & \multicolumn{2}{|c|}{ Compound $2 * *$} \\
\hline & $\delta_{C}$ & $\delta_{H}$ & $\delta_{C}$ & $\delta_{H}$ \\
\hline 2 & 163.7 & 1 & 157.7 & 1 \\
\hline 3 & 103.7 & $6.88(\mathrm{~s})$ & 133.9 & I \\
\hline 4 & 182.2 & 1 & 177.8 & l \\
\hline 5 & 157.7 & I & 161.6 & l \\
\hline 6 & 99.3 & $6.21(\mathrm{~d}, 2.1)$ & 98.6 & $6.23(\mathrm{~d}, 2.1)$ \\
\hline 7 & 164.6 & 1 & 164.8 & 1 \\
\hline 8 & 94.5 & $6.49(\mathrm{~d}, 2.1)$ & 93.3 & $6.42(\mathrm{~d}, 2.2)$ \\
\hline 9 & 161.8 & 1 & 157.0 & 1 \\
\hline 10 & 104.1 & I & 104.1 & l \\
\hline $1^{\prime}$ & 121.9 & I & 122.1 & I \\
\hline $2^{\prime}$ & 114.0 & $7.67(\mathrm{~d}, 2.2)$ & 115.7 & $7.62(\mathrm{~d}, 2.2)$ \\
\hline $3^{\prime}$ & 145.5 & 1 & 144.6 & 1 \\
\hline $4^{\prime}$ & 151.1 & I & 148.5 & l \\
\hline $5^{\prime}$ & 117.0 & $6.99(\mathrm{~d}, 8.4)$ & 114.5 & $6.86(\mathrm{~d}, 8.4)$ \\
\hline $6^{\prime}$ & 122.2 & $7.65(\mathrm{dd}, 2.2,8.4)$ & 121.4 & $7.65(\mathrm{~d}, 2.2)$ \\
\hline $1^{\prime \prime}$ & 100.8 & $5.27(\mathrm{~d}, 7.5)$ & 102.9 & $5.31(\mathrm{~d}, 7.8)$ \\
\hline
\end{tabular}

\begin{tabular}{lllll}
\hline \multirow{2}{*}{ Position } & \multicolumn{2}{l}{ Compound 1* } & \multicolumn{2}{l}{ Compound 2** } \\
\cline { 2 - 5 } & $\boldsymbol{\delta}_{\boldsymbol{C}}$ & $\boldsymbol{\delta}_{\boldsymbol{H}}$ & $\boldsymbol{\delta}_{\boldsymbol{C}}$ & $\boldsymbol{\delta}_{\boldsymbol{H}}$ \\
\hline $2^{\prime \prime}$ & 73.3 & $3.38(\mathrm{~m})$ & 73.9 & $3.55(\mathrm{~m})$ \\
$3^{\prime \prime}$ & 75.7 & $3.39(\mathrm{~m})$ & 76.0 & $3.48(\mathrm{~m})$ \\
$4^{\prime \prime}$ & 71.7 & $3.48(\mathrm{~m})$ & 71.2 & $3.60(\mathrm{~m})$ \\
$5^{\prime \prime}$ & 75.5 & $4.23(\mathrm{~d}, 9.7)$ & 75.8 & $3.75(\mathrm{~d}, 9.8)$ \\
$6^{\prime \prime}$ & 169.2 & $/$ & 168.7 & $/$ \\
$1^{\prime \prime \prime}$ & 64.8 & $4.05(\mathrm{~m}) 4.13(\mathrm{~m})$ & 64.8 & $4.08(\mathrm{t}, 6.5)$ \\
$2^{\prime \prime \prime}$ & 30.5 & $1.51(\mathrm{~m})$ & 30.1 & $1.52(\mathrm{~m})$ \\
$3^{\prime \prime \prime}$ & 18.9 & $1.24,(\mathrm{q}, 7.5)$ & 18.5 & $1.26(\mathrm{~m})$ \\
$4^{\prime \prime \prime}$ & 13.9 & $0.74(\mathrm{t}, 7.4)$ & 12.5 & $0.84(\mathrm{dt}, 8.8,7.4)$ \\
$\mathrm{OH}_{5}$ & & $12.96(\mathrm{~s})$ & $/$ & $/$ \\
\hline
\end{tabular}

*Recorded in DMSO-d6; ${ }^{1} \mathrm{H}(600 \mathrm{MHz}) ;{ }^{13} \mathrm{C}(150 \mathrm{MHz}) .{ }^{* *}$ Recorded in $\mathrm{CD}_{3} \mathrm{OD} ;{ }^{1} \mathrm{H}(600 \mathrm{MHz}) ;{ }^{13} \mathrm{C}(150 \mathrm{MHz})$.

\subsection{Characterization of Semi-synthetic Derivatives from Compound 5}

The $O$-alkylation using prenyl bromide afforded four semisynthetic flavanone derivatives (Figure 3) namely: 6,4'-Odiprenyl-apigenin-7- $O-\beta$ - $_{\mathrm{D}}$-glucopyranoside (5a), 8- $C$-prenyl6,4'-O-diprenyl-apigenin-7- $O-\beta$ - - -glucopyranoside $(5 \mathrm{~b}), 8-C$ prenyl-4'-O-prenyl-apigenin-7-O- $\beta$ - $_{\mathrm{D}}$-glucopyranoside $\quad(5 \mathrm{c})$, 4'- $O$-prenyl-apigenin-7- $O-\beta{ }_{-}$-glucopyranoside $(5 \mathrm{~d})$.

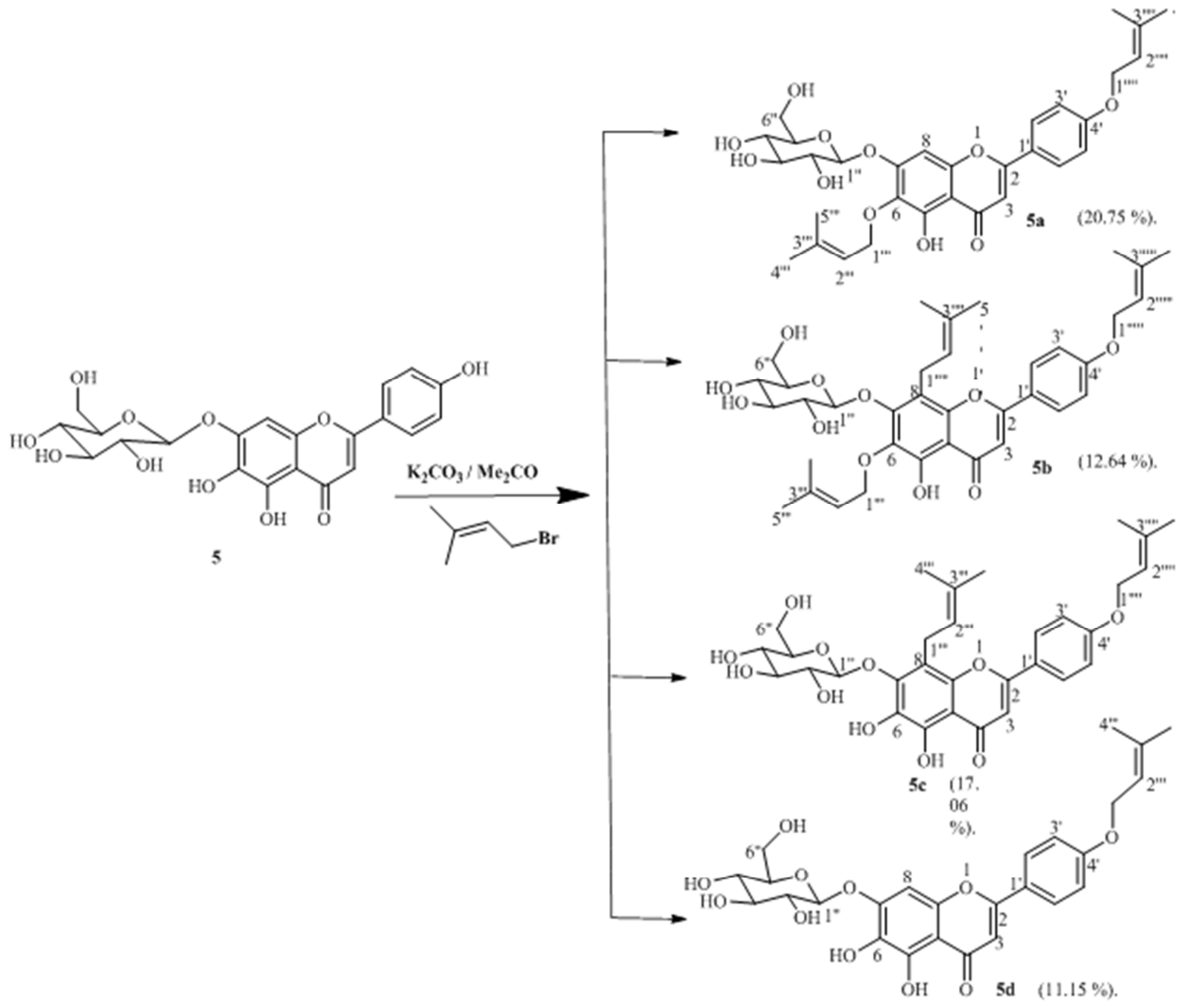

Figure 3. General scheme of the semi-synthesis of compounds 5 a-5d from 5.

6,4'-O-diprenyl-apigenin-7- $O-\beta$-D -glucopyranoside (5a), was obtained as a yellow amorphous powder. HRESI-MS: $m / z$ 607.2218 [M+Na] ${ }^{+}$(Calcd. for $\mathrm{C}_{31} \mathrm{H}_{36} \mathrm{O}_{11} \mathrm{Na}$ : 607.2155), $\mathrm{m} / z 1191.4543[2 \mathrm{M}+\mathrm{Na}]^{+}$and $\mathrm{m} / z 583.2193$ [M-H] $^{-}$(Calcd. for $\mathrm{C}_{31} \mathrm{H}_{35} \mathrm{O}_{11}:$ : 583.2179). ${ }^{1} \mathrm{H}$ NMR $\left(500 \mathrm{MHz}, \mathrm{CDCl}_{3}\right)$ and ${ }^{13} \mathrm{C}$ NMR $\left(125 \mathrm{MHz}, \mathrm{CDCl}_{3}\right)$ data: See Table 2 and Table 3. 8 - $C$-prenyl-6,4'-O-diprenyl-apigenin-7- $O-\beta$ - D- $^{-}$ glucopyranoside (5b) was obtained as yellow amorphous powder. HRESI-MS: $m / z 653.2927[\mathrm{M}+\mathrm{H}]^{+}$(Calcd. for $\mathrm{C}_{36} \mathrm{H}_{45} \mathrm{O}_{11}: 653.2962$ ); m/z $675.2736[\mathrm{M}+\mathrm{Na}]^{+}$(Calcd. for $\mathrm{C}_{36} \mathrm{H}_{44} \mathrm{O}_{11} \mathrm{Na}: 675.2781$ ) and $\mathrm{m} / z$ 651.2860 [M-H] ${ }^{-}$(Calcd. for $\left.\mathrm{C}_{36} \mathrm{H}_{43} \mathrm{O}_{11}: 651.2805\right)$. ${ }^{1} \mathrm{H}$ NMR $\left(500 \mathrm{MHz}, \mathrm{CDCl}_{3}\right)$ and ${ }^{13} \mathrm{C}$ NMR $\left(125 \mathrm{MHz}, \mathrm{CDCl}_{3}\right)$ data: See Table 2 and Table 3. 8- $C$-prenyl-4'- $O$-prenyl-apigenin-7- $O-\beta$ - - $_{\text {-glucopyranoside }}$ 
(5c), was obtained as yellow amorphous powder. HRESIMS: $m / z 585.2335[\mathrm{M}+\mathrm{H}]^{+}$(Calcd. for $\mathrm{C}_{31} \mathrm{H}_{37} \mathrm{O}_{11}$ : 585.2336). ${ }^{1} \mathrm{H}$ NMR $\left(500 \mathrm{MHz}, \mathrm{CDCl}_{3}\right)$ and ${ }^{13} \mathrm{C}$ NMR $(125 \mathrm{MHz}$, $\mathrm{CDCl}_{3}$ ) data: See Table 2 and Table 3.

4'- $O$-prenyl-apigenin-7- $O-\beta{ }_{-}$- -glucopyranoside (5d) was obtained as yellow amorphous powder. HRESI-MS: $\mathrm{m} / \mathrm{z}$ 517.1755 $[\mathrm{M}+\mathrm{H}]^{+}$(Calcd. for $\mathrm{C}_{26} \mathrm{H}_{29} \mathrm{O}_{11}$ : 517.1710). ${ }^{1} \mathrm{H}$ NMR $\left(500 \mathrm{MHz}, \mathrm{CDCl}_{3}\right)$ and $\left.{ }^{13} \mathrm{C} \mathrm{NMR} \mathrm{(125} \mathrm{MHz}, \mathrm{CDCl}_{3}\right)$ data: See Table 2 and Table 3.

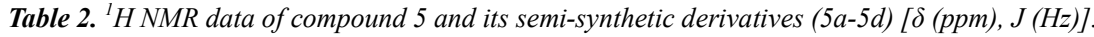

\begin{tabular}{|c|c|c|c|c|c|}
\hline Position & Compound 5* & Compound 5a** & Compound 5b** & Compound 5c** & Compound 5d** \\
\hline \multicolumn{6}{|l|}{$\delta_{\mathrm{H}}$} \\
\hline H-3 & $6.84(\mathrm{~s})$ & $6.64(s)$ & $6.64(s)$ & $6.69(\mathrm{~s})$ & $6.71(\mathrm{~s})$ \\
\hline $\mathrm{H}-8$ & $7.02(\mathrm{~s})$ & $6.88(\mathrm{~s})$ & / & / & $7.06(\mathrm{~s})$ \\
\hline $\mathrm{H}-2^{\prime} / \mathrm{H}-6^{\prime}$ & $7.94(\mathrm{~d}, 8.8)$ & $7.92(\mathrm{~d}, 8.9)$ & $7.83(\mathrm{~d}, 8.9)$ & $7.94(\mathrm{~d}, 8.6)$ & $7.99(\mathrm{~d}, 8.9)$ \\
\hline $\mathrm{H}-3^{\prime} / \mathrm{H}-5^{\prime}$ & $6.94(\mathrm{~d}, 8.8)$ & $7.05(\mathrm{~d}, 8.9)$ & $7.03(\mathrm{~d}, 8.9)$ & $7.08(\mathrm{~d}, 8.6)$ & $7.09(\mathrm{~d}, 8.9)$ \\
\hline $\mathrm{H}-1^{\prime \prime}$ & $5.01(\mathrm{~d}, 7.5)$ & $5.06(\mathrm{~d}, 7.6)$ & $4.92(\mathrm{~d}, 7.6)$ & $4.99(\mathrm{~d}, 7.8)$ & $5.09(\mathrm{~d}, 7.6)$ \\
\hline $\mathrm{H}-2^{\prime \prime}$ & $3.33(\mathrm{~m})$ & $3.61(\mathrm{~m})$ & $3.65(\mathrm{~m})$ & $3.58(\mathrm{t}, 8.3)$ & $3.61(\mathrm{~m})$ \\
\hline $\mathrm{H}-4^{\prime \prime}$ & $3.46(\mathrm{dd}, 9.2,9.2)$ & $3.48(\mathrm{~m})$ & $3.68(\mathrm{~m})$ & $3.45(\mathrm{~m})$ & 3.43 (bs) \\
\hline $\mathrm{H}-5^{\prime \prime}$ & $3.46(\mathrm{~m})$ & $3.56(\mathrm{~m})$ & $3.64(\mathrm{~m})$ & $3.31(\mathrm{~m})$ & $3.60(\mathrm{~m})$ \\
\hline \multirow{2}{*}{ H-6" } & $3.48(\mathrm{~d}, 2.1)$ & $3.76(d, 7.5)$ & $3.88(\mathrm{~d}, 3.4)$ & $3.85(\mathrm{~d}, 2.4)$ & $3.98(\mathrm{~d}, 2.3)$ \\
\hline & $3.76(d, 3.9)$ & $3.96(\mathrm{~d}, 2.5)$ & $3.80(\mathrm{~d}, 4.8)$ & $3.75(\mathrm{~d}, 5.1)$ & $3.76(\mathrm{~d}, 6.1)$ \\
\hline & -5 & $4.66(\mathrm{nd})$ & $4.65(\mathrm{~d}, 3.7)$ & $3.86(\mathrm{~d}, 2.4)$ & \multirow{2}{*}{$4.66(d, 6.6)$} \\
\hline H-I & 1 & $4.56(\mathrm{~d}, 7.6)$ & $4.81(\mathrm{~d}, 3.8)$ & $3.74(\mathrm{~d}, 5.1)$ & \\
\hline $\mathrm{H}-2^{\prime \prime \prime}$ & l & $5.59(\mathrm{~m})$ & $5.59(\mathrm{td}, 6.8,6.3,3.8)$ & $5.27(\mathrm{t}, 6.7)$ & $5.50(\mathrm{~m})$ \\
\hline H-4"' & l & $1.74(\mathrm{~s})$ & $1.80(\mathrm{~s})$ & $1.71(\mathrm{~s})$ & $1.80(\mathrm{~s})$ \\
\hline H-5"' & l & $1.77(\mathrm{~s})$ & $1.80(\mathrm{~s})$ & $1.87(\mathrm{~s})$ & $1.83(\mathrm{~s})$ \\
\hline H-1"'"' & l & $4.63(\mathrm{~d}, 6.4)$ & $3.71(\mathrm{~d}, 5.5)$ & $4.66(d, 6.7)$ & / \\
\hline H-2'"' & l & $5.49(\mathrm{~m})$ & $5.24(\mathrm{bs})$ & $5.50(\mathrm{~d}, 6.8)$ & l \\
\hline H-3"'"' & l & / & 1 & l & / \\
\hline H-4"'"' & l & $1.78(\mathrm{~s})$ & $1.81(\mathrm{~s})$ & $1.82(\mathrm{~s})$ & / \\
\hline H-5'"'! & l & $1.81(\mathrm{~s})$ & $1.81(\mathrm{~s})$ & $1.80(\mathrm{~s})$ & l \\
\hline H-1"'"' & l & 1 & $6.62(\mathrm{~d}, 6.8)$ & 1 & / \\
\hline H-2"'"' & l & l & $5.52(\mathrm{dd}, 6.7,5.3)$ & I & l \\
\hline H-3"'"' & l & l & 1 & l & / \\
\hline H-4"'"' & l & 1 & $1.86(\mathrm{~s})$ & l & l \\
\hline H-5"'"' & l & l & $1.84(\mathrm{~s})$ & l & l \\
\hline $\mathrm{OH}_{5}$ & $12.73(\mathrm{~s})$ & 1 & 1 & 1 & 1 \\
\hline
\end{tabular}

${ }^{1} \mathrm{H}$ NMR *Recorded in (DMSO- $\left.d_{6}, 600 \mathrm{MHz}\right) ; * *$ Recorded in $\left(\mathrm{CDCl}_{3}, 500 \mathrm{MHz}\right)$; nd: not determined. bs: broad single.

Table 3. ${ }^{13}$ C NMR data of substrate (5) and its semi-synthetic derivatives (5a-5d) [ $\left.\delta(p p m)\right]$.

\begin{tabular}{|c|c|c|c|c|c|}
\hline Position & Compound 5* & Compound 5a** & Compound 5b** & Compound 5c** & Compound 5d** \\
\hline & $\delta_{\mathrm{C}}$ & & & & \\
\hline $\mathrm{C}-2$ & 164.5 & 165.2 & 164.6 & 165.2 & 164.6 \\
\hline $\mathrm{C}-3$ & 102.9 & 103.2 & 103.8 & 102.4 & 102.5 \\
\hline C-4 & 182.9 & 182.9 & 183.4 & 183.5 & 182.8 \\
\hline $\mathrm{C}-5$ & 147.0 & 153.2 & 150.4 & 147.1 & 151.6 \\
\hline C-6 & 130.9 & 131.0 & 134.6 & 134.0 & 130.6 \\
\hline $\mathrm{C}-7$ & 151.8 & 156.6 & 153.5 & 148.8 & 159.1 \\
\hline $\mathrm{C}-8$ & 94.5 & 94.2 & 114.6 & 114.8 & 94.5 \\
\hline C-9 & 149.5 & 153.1 & 151.7 & 145.1 & 149.1 \\
\hline C-10 & 106.2 & 106.5 & 109.4 & 107.9 & 106.2 \\
\hline $\mathrm{C}-1^{\prime}$ & 121.7 & 122.9 & 123.4 & 122.9 & 122.9 \\
\hline $\mathrm{C}-2^{\prime} / \mathrm{C}-6^{\prime}$ & 128.4 & 128.2 & 128.1 & 127.9 & 127.9 \\
\hline $\mathrm{C}-3^{\prime} / \mathrm{C}-5^{\prime}$ & 116.3 & 115.1 & 115.3 & 114.9 & 114.9 \\
\hline C- $4^{\prime}$ & 161.7 & 162.2 & 162.1 & 162.3 & 162.0 \\
\hline $\mathrm{C}-1^{\prime \prime}$ & 101.4 & 100.8 & 105.2 & 104.5 & 101.2 \\
\hline $\mathrm{C}-2^{\prime \prime}$ & 73.6 & 73.3 & 74.3 & 74.2 & 73.3 \\
\hline C-3" & 76.3 & 76.3 & 76.1 & 76.6 & 76.0 \\
\hline C-4" & 70.1 & 69.9 & 69.9 & 69.8 & 69.8 \\
\hline C-5" & 77.8 & 76.9 & 76.7 & 77.2 & 77.9 \\
\hline C-6" & 61.1 & 61.5 & 62.1 & 61.1 & 61.3 \\
\hline C-1"' & I & 69.6 & 70.1 & 22.6 & 64.8 \\
\hline C-2'"' & I & 119.6 & 119.5 & 123.4 & 119.2 \\
\hline C-3"' & I & 139.8 & 140.2 & 131.3 & 137.9 \\
\hline C-4"' & I & 17.5 & 18.3 & 17.1 & 16.8 \\
\hline C-5"' & 1 & 25.2 & 25.9 & 24.4 & 24.4 \\
\hline
\end{tabular}




\begin{tabular}{|c|c|c|c|c|c|}
\hline Position & Compound 5* & Compound 5a** & Compound 5b** & Compound $5 c^{* * *}$ & Compound 5d** \\
\hline & $\delta_{\mathrm{C}}$ & & & & \\
\hline C-1"'"' & 1 & 64.9 & 23.1 & 64.8 & 1 \\
\hline C-2"'"' & I & 118.9 & 122.9 & 119.2 & I \\
\hline C-3"'"' & l & 138.5 & 132.8 & 138.0 & I \\
\hline C-4"'"' & I & 17.6 & 18.1 & 16.8 & I \\
\hline C-5 $5^{\prime \prime \prime \prime}$ & I & 25.2 & 25.5 & 24.4 & I \\
\hline C-1"'"'" & I & I & 65.2 & I & I \\
\hline C-2'"'"' & I & 1 & 118.9 & I & I \\
\hline C-3"'"'" & I & I & 139.0 & I & I \\
\hline C-4"'"'! & 1 & l & 18.2 & 1 & l \\
\hline C-5"'"'"' & 1 & 1 & 25.8 & 1 & 1 \\
\hline
\end{tabular}

${ }^{13} \mathrm{C}$ NMR *Recorded in (DMSO- $\left.d_{6}, 150 \mathrm{MHz}\right) ; * *$ Recorded in $\left(\mathrm{CDCl}_{3}, 125 \mathrm{MHz}\right)$.

\subsection{Antibacterial Analysis}

The antibacterial activity of the $\mathrm{MeOH}$ extract, the $n$ $\mathrm{BuOH}$ and EtOAc fractions as well as the aqueous residue and some major isolated compounds was examined by microdilution susceptibility assay against Salmonella bacteria. Table 4 presents the inhibition parameters (MIC, $\mathrm{MBC}$ and $\mathrm{MBC} / \mathrm{MIC}$ ratio) of the extracts, various fractions, isolated compounds from Tristemma hirtum and three semisynthetic derivatives (5a-5c). From this table, all extracts and fractions inhibited the growth of Salmonella with MICs varying from 24 to $1536 \mu \mathrm{g} / \mathrm{mL}$. The $\mathrm{MeOH}$ extract and EtOAc fraction inhibited two and three tested bacteria strains, respectively with MICs lower than $100 \mu \mathrm{g} / \mathrm{mL}$. The isolated compounds presented MICs between 16 and 256 $\mu \mathrm{g} / \mathrm{mL}$. Compounds 1, 3 and 11 exhibited the best inhibitory parameters with MICs lower than $100 \mu \mathrm{g} / \mathrm{mL}$ against ST, SPA and STM, respectively. Most of the extracts and compounds presented the ratio $\mathrm{MBC} / \mathrm{MIC}$ equal or low than 4. All these inhibition parameters remain not significant compared to ciprofloxacin used as reference.

Table 4. Minimal Inhibitory Concentration (MIC) and Minimal Bactericidal Concentration (MBC) of various extract, fractions and isolated components from Tristemma hirtum with some semi synthetics derivatives against Salmonella bacteria.

\begin{tabular}{|c|c|c|c|c|c|c|}
\hline \multicolumn{2}{|c|}{$\begin{array}{l}\text { Extract, fractions, isolated compounds and semi } \\
\text { synthetic derivatives }\end{array}$} & \multirow{2}{*}{$\begin{array}{l}\text { Salmonella } \\
\text { Typhi } \\
96\end{array}$} & \multirow{2}{*}{$\begin{array}{l}\text { Salmonella Typhi } \\
\text { (ATCC 6539) }\end{array}$} & \multirow{2}{*}{$\begin{array}{c}\begin{array}{c}\text { Salmonella } \\
\text { Paratyphi A }\end{array} \\
384\end{array}$} & \multirow{2}{*}{$\begin{array}{l}\begin{array}{l}\text { Salmonella } \\
\text { Paratyphi B }\end{array} \\
96\end{array}$} & \multirow{2}{*}{$\begin{array}{l}\begin{array}{l}\text { Salmonella } \\
\text { Typhimurium }\end{array} \\
192\end{array}$} \\
\hline & $\mathrm{MIC}(\mu \mathrm{g} / \mathrm{mL})$ & & & & & \\
\hline $\mathrm{MeOH}$ extract & $\operatorname{MBC}(\mu \mathrm{g} / \mathrm{mL})$ & 384 & 768 & 1536 & 96 & 768 \\
\hline & $\mathrm{MBC} / \mathrm{MIC}$ & 4 & 1 & 4 & 1 & 4 \\
\hline \multirow{3}{*}{ EtOAc fraction } & $\operatorname{MIC}(\mu \mathrm{g} / \mathrm{mL})$ & 384 & 96 & 96 & 384 & 192 \\
\hline & $\operatorname{MBC}(\mu \mathrm{g} / \mathrm{mL})$ & 384 & 192 & 96 & 768 & 384 \\
\hline & $\mathrm{MBC} / \mathrm{MIC}$ & 1 & 2 & 1 & 2 & 2 \\
\hline \multirow[t]{2}{*}{$n$-BuOH fraction } & $\operatorname{MBC}(\mu \mathrm{g} / \mathrm{mL})$ & 1536 & 1536 & 768 & 768 & 384 \\
\hline & $\mathrm{MBC} / \mathrm{MIC}$ & 1 & 2 & 4 & 1 & 2 \\
\hline \multirow{3}{*}{ Aqueous residual fraction } & $\operatorname{MIC}(\mu \mathrm{g} / \mathrm{mL})$ & 768 & 768 & 768 & 384 & 1536 \\
\hline & $\operatorname{MBC}(\mu \mathrm{g} / \mathrm{mL})$ & 768 & 768 & 1536 & - & 1536 \\
\hline & $\mathrm{MBC} / \mathrm{MIC}$ & 1 & 1 & 2 & / & 1 \\
\hline \multirow[b]{2}{*}{1} & $\mathrm{MIC}(\mu \mathrm{g} / \mathrm{mL})$ & 64 & 64 & / & / & 32 \\
\hline & $\operatorname{MBC}(\mu \mathrm{g} / \mathrm{mL})$ & 128 & 256 & l & l & 64 \\
\hline \multirow[t]{2}{*}{3} & $\mathrm{MBC}(\mu \mathrm{g} / \mathrm{mL})$ & $>64$ & $>64$ & $>64$ & 64 & 64 \\
\hline & $\mathrm{MBC} / \mathrm{MCI}$ & / & I & I & 1 & 2 \\
\hline \multirow{3}{*}{4} & $\mathrm{MIC}(\mu \mathrm{g} / \mathrm{mL})$ & 128 & 128 & 128 & 64 & 64 \\
\hline & $\operatorname{MBC}(\mu \mathrm{g} / \mathrm{mL})$ & / & 512 & 128 & 256 & 256 \\
\hline & $\mathrm{MBC} / \mathrm{MCI}$ & / & 4 & 1 & 4 & 4 \\
\hline \multirow{3}{*}{5} & MI C $(\mu \mathrm{g} / \mathrm{mL})$ & 64 & 128 & 32 & 128 & 32 \\
\hline & $\operatorname{MBC}(\mu \mathrm{g} / \mathrm{mL})$ & 128 & 256 & 128 & 512 & 128 \\
\hline & $\mathrm{MBC} / \mathrm{MCI}$ & 2 & 2 & 4 & 4 & 4 \\
\hline \multirow{3}{*}{$5 a$} & $\mathrm{MIC}(\mu \mathrm{g} / \mathrm{mL})$ & 128 & 64 & 32 & 32 & 16 \\
\hline & $\operatorname{MBC}(\mu \mathrm{g} / \mathrm{mL})$ & 256 & 256 & 128 & 128 & 128 \\
\hline & $\mathrm{MBC} / \mathrm{MCI}$ & 2 & 4 & 4 & 4 & 8 \\
\hline \multirow{3}{*}{$5 b$} & MI C $(\mu \mathrm{g} / \mathrm{mL})$ & 128 & 128 & 256 & 128 & 128 \\
\hline & $\operatorname{MBC}(\mu \mathrm{g} / \mathrm{mL})$ & 512 & 256 & 512 & 512 & 512 \\
\hline & $\mathrm{MBC} / \mathrm{MCI}$ & 4 & 2 & 2 & 4 & 4 \\
\hline $5 c$ & MI C $(\mu \mathrm{g} / \mathrm{mL})$ & 32 & 32 & 64 & 128 & 32 \\
\hline \multirow{2}{*}{9} & MI C $(\mu \mathrm{g} / \mathrm{mL})$ & 128 & 128 & 256 & 128 & 32 \\
\hline & $\operatorname{MBC}(\mu \mathrm{g} / \mathrm{mL})$ & 1 & 512 & 1 & 1 & 128 \\
\hline
\end{tabular}




\begin{tabular}{|c|c|c|c|c|c|c|}
\hline \multicolumn{2}{|c|}{$\begin{array}{l}\text { Extract, fractions, isolated compounds and semi } \\
\text { synthetic derivatives }\end{array}$} & \multirow{2}{*}{$\begin{array}{l}\text { Salmonella } \\
\text { Typhi } \\
/\end{array}$} & \multirow{2}{*}{$\begin{array}{l}\text { Salmonella Typhi } \\
\text { (ATCC 6539) } \\
4\end{array}$} & \multirow{2}{*}{$\begin{array}{l}\text { Salmonella } \\
\text { Paratyphi A }\end{array}$} & \multirow{2}{*}{$\begin{array}{l}\begin{array}{l}\text { Salmonella } \\
\text { Paratyphi B }\end{array} \\
/\end{array}$} & \multirow{2}{*}{$\begin{array}{l}\begin{array}{l}\text { Salmonella } \\
\text { Typhimurium }\end{array} \\
4\end{array}$} \\
\hline & $\mathrm{MBC} / \mathrm{MCI}$ & & & & & \\
\hline \multirow{4}{*}{10} & MI C $(\mu \mathrm{g} / \mathrm{mL})$ & 128 & 128 & 128 & 64 & 128 \\
\hline & $\operatorname{MBC}(\mu \mathrm{g} / \mathrm{mL})$ & 512 & 1 & 512 & 256 & 512 \\
\hline & $\mathrm{MBC} / \mathrm{MCI}$ & 4 & / & 4 & 4 & 4 \\
\hline & MI C $(\mu \mathrm{g} / \mathrm{mL})$ & 32 & 16 & 32 & 64 & 64 \\
\hline \multirow[t]{2}{*}{11} & $\operatorname{MBC}(\mu \mathrm{g} / \mathrm{mL})$ & 128 & 128 & 128 & 256 & 128 \\
\hline & $\mathrm{MBC} / \mathrm{MCI}$ & 4 & 8 & 4 & 4 & 2 \\
\hline \multirow{3}{*}{ Ciprofloxacin } & $\mathrm{MIC}(\mu \mathrm{g} / \mathrm{mL})$ & 0,375 & 0,375 & 0,1875 & 0,1875 & 0,375 \\
\hline & $\operatorname{MBC}(\mu \mathrm{g} / \mathrm{mL})$ & 0,375 & 0,375 & 0,375 & 0,1875 & 0,375 \\
\hline & $\mathrm{MBC} / \mathrm{MIC}$ & 1 & 1 & 2 & 1 & 1 \\
\hline
\end{tabular}

$\mathrm{MIC}=$ Minimal Inhibitory concentration. $\mathrm{MBC}=$ Minimal Bactericidal Concentration; /: not determined; -: more than $1536 \mu \mathrm{g} / \mathrm{mL}$.

\subsection{Discussion}

The antibacterial activity of a plant extract is considered to be highly active if the MIC $<100 \mu \mathrm{g} / \mathrm{mL}$, significantly active when $100 \leq \mathrm{MIC} \leq 512 \mu \mathrm{g} / \mathrm{mL}$, moderately active when $512<$ $\mathrm{MIC} \leq 2048 \mu \mathrm{g} / \mathrm{mL}$, weakly active if MIC $>2048 \mu \mathrm{g} / \mathrm{mL}$ and not active when MIC $>10,000 \mu \mathrm{g} / \mathrm{mL}$ [33]. The antibacterial activity of extracts and fractions showed MICs varying from 24 to $1536 \mu \mathrm{g} / \mathrm{mL}$ against five bacteria strains of the Salmonella genus (Table 4). The $\mathrm{MeOH}$ extract of Tristemma hirtum was highly active (MIC $<100 \mu \mathrm{g} / \mathrm{mL}$ ) against two bacterial species (Salmonella typhi, Salmonella paratyphi B) and significantly active $(100 \leq$ MIC $\leq 512 \mu \mathrm{g} / \mathrm{mL})$ against Salmonella paratyphi A and Salmonella typhimurium. The EtOAc fraction also was highly active against Salmonella typhi ATCC6539 and Salmonella paratyphi A; significantly active against Salmonella typhi, Salmonella paratyphi B and Salmonella typhimurium. Despite the significant activity on just two bacterial strains (Salmonella paratyphi A, Salmonella typhimurium), the $n-\mathrm{BuOH}$ fraction was also purified according to its abundance of phenolic components which were shown to be active against many bacterial strains [12].

Antimicrobial cut-off points have been defined in the literature to enable the understanding of the effectiveness of pure compounds as follows: highly active when MIC $<1$ $\mu \mathrm{g} / \mathrm{mL}$ (or $2.5 \mu \mathrm{M}$ ), significantly active for $1 \leq \mathrm{MIC} \leq 10$ $\mu \mathrm{g} / \mathrm{mL}$ (or $2.5 \leq \mathrm{MIC}<25 \mu \mathrm{M}$ ), moderately active when $10<$ $\mathrm{MIC} \leq 100 \mu \mathrm{g} / \mathrm{mL}$ ( or $25<\mathrm{MIC} \leq 250 \mu \mathrm{M}$ ), weakly active for $100<\mathrm{MIC} \leq 1000 \mu \mathrm{g} / \mathrm{mL}$ (or $250<\mathrm{MIC} \leq 2500 \mu \mathrm{M}$ ) and not active when $\mathrm{MIC}>1000 \mu \mathrm{g} / \mathrm{mL}$ (or $>2500 \mu \mathrm{M}$ ) [33]. Based on this cut-off, the antibacterial activities of all the tested isolated compounds could be considered as significant or moderate against the specific microorganisms. They showed MIC values from 16 to $256 \mu \mathrm{g} / \mathrm{mL}$. Compounds 3 and 11 were moderately active (MIC $=16 \mu \mathrm{g} / \mathrm{mL}$ ) against Salmonella paratyphi A and Salmonella typhi ATCC6539, respectively. Compounds 1, 4, 5, 9 and 10 are also moderately active (MIC from 16 to $64 \mu \mathrm{g} / \mathrm{mL}$ ) and then, could justify the activity shown by the original fraction, suggesting that many of them should proceed by synergism to enable the higher activity of the extract. This potentiating effect of the methanol extract from leaves of $T$. hirtum against Multi-Drugs Resistant Gram-Negative Bacteria have been reported when it was combined with other antibiotics [16]. Compound 5 as a substrate of prenylation reaction showed moderate activity against three bacteria strains tested while two of its semi-synthetic derivatives, $5 \mathrm{a}$ and $5 \mathrm{c}$ showed the same activity against four various bacterial strains. This observed activity may be due to the prenylated chain because it is reported that the addition of a prenyl groups to an aromatic secondary metabolite often results in a derivative with improved or modified pharmacological activity [34]. These "hybrid" natural products nowadays represent a new frontier for the development of novel drugs, and particularly as antibacterial agents [34].

According to the criteria used by Gatsing and Adoga, the antibacterial substance is considered as bactericidal, when $\mathrm{MBC} / \mathrm{MIC} \leq 4$ and bacteriostatic, when $\mathrm{MBC} / \mathrm{MIC}>4$ [35]. Based on those criteria, the large majority of these extracts and isolated compounds are bactericidal. Bactericidal activity of a Tristemma mauritianum extract was already presented by Ngoudjou [12]. In addition, many plant extracts and isolated compounds from the Melastomataceae family are known for their antibacterial activity $[9,11]$. The isolated compounds found to be active in the present study are members of the triterpenoid, flavonoid, and phenolic acid groups. Although triterpenoid, flavonoid, and phenolic acid compounds have been reported to possess antibacterial activity [36], no study has reported the activity of these compounds about pathogenic bacterial strains used in the present study.

The activity of flavonoids is probably due to their ability to form complexes with extracellular and soluble proteins and to form complexes with bacterial cell wall components as previously described by Cowan [37]. In addition, previous studies revealed that, lipophilic flavonoids may also upset microbial membranes, hence a possible mechanism by which a prenyl group may modify the biological activity of flavonoids is through enhancement of lipophilicity [38]. Furthermore, they notice that insertion of a prenyl chain into a molecule increases its lipophilicity which could modify its biological activity through improve approach, affinity and interaction with the lipophilic membrane [38]. However, further studies are needed to show the detailed mechanisms by which the prenyl group influences biological activity.

\section{Conclusion}

Eleven compounds were isolated from the aerial parts of Tristemma hirtum including two new esterified glucuronic flavonoids. Furthermore, four new semi synthetic derivatives 
were obtained from prenylation of 6-hydroxyapigenin-7- $O-\beta{ }_{-}{ }^{-}$ glucopyranoside. The structures of all the compounds were elucidated mainly by NMR and mass spectrometric data. It appears that the $\mathrm{MeOH}$ extract and the EtOAc fraction from Tristemma hirtum, as well as luteolin- $3^{\prime}-O-\beta{ }^{-} \mathrm{D}^{-}$ glucuronopyranosylbutyl ester (1), luteolin (3) and casuarinine (11) possess the most potent antibacterial property. These results highlight the traditional use of Tristemma hirtum in the treatment of infectious diseases, especially those caused by the tested microorganisms. Therefore, Tristemma hirtum may be a good candidate for the search of phytodrugs against salmonellosis.

\section{Acknowledgements}

The authors are grateful to the Alexander von Humboldt Foundation $(\mathrm{AvH})$, Bonn, Germany for the financial support of this work. We thank the Rhineland Platinate Center of Natural Products Research (Mainz, Germany) for funding part of the analytical chemistry involved. We would also like to thank the Yaoundé-Bielefeld Bilateral Graduate School Natural Products with Antiparasite and Antibacterial Activities (YaBiNaPA) for recording the mass spectra of some of the isolated compounds.

\section{Conflicts of Interest}

The authors declare that they have no competing interests.

\section{References}

[1] Kashmira, A., Date, M. D., Adwoa, D. B., Kimberley, K. F., Nihal, A., Mintz, E. D., Khan, M. I., Sushant, S., Terri, B. H. (2014). Typhoid fever surveillance and vaccine use - SouthEast Asia and Western Pacific Regions, 2009-2013. Morbidity and Mortality Weekly Report, 63: 855-860.

[2] Gatsing, D., Moudji, S. T., Kuiate, J. R., Nji-Nkah, B. F., Fodouop, S. P. C., Njateng, G. S. S., Tchakouté, V., Nkeugouapi, C. F. N., Tchouanguep, M. F. (2008). In vitro antibacterial activity of Alchornea cordifolia bark extract against Salmonella species causing typhoid fevers. Ethiopian Journal of Pharmacology, 26: 83-94.

[3] Muthumbi, E., Etyang, A. O., Morpeth, S. C., Berkley, J. A., Ooko, M., Mwanzu, A., Williams, T. N., Mwarumba, S., Kariuki, S., Mturi, N., Scott, J. A. G. (2015). Invasive salmonellosis in Kilifi, Kenya. Clinical Infectious Diseases, 61: 290-301.

[4] Siddiqui, T. R., Bibi, S., Mustufa, M. A., Ayaz, S. M., Khan, A. (2015). High prevalence of typhoidal Salmonella enterica serovars excreting food handlers in Karachi-Pakistan: a probable factor for regional typhoid endemicity. Journal of Health, Population and Nutrition, 33: 1-9.

[5] Dahikar, S. G., Deshmukh, S. S., Thakare, P. V. (2014). Mutation at quinolone resistance-determining region of gyrA gene of Salmonella typhi isolated from tertiary health care hospitals of Amravati, Maharashtra. International Journal of Current Microbiology and Applied Sciences, 3: 487-495.
[6] Su, L. H., Chiu, C. H. (2007). Salmonella: Clinical importance and evaluation of nomenclature. Chang Gung Medical Journal, 30: 210-219.

[7] Jantsch, J., Chikkaballi, D., Hensel, M. (2011). Cellular aspects of immunity to intracellular Salmonella enterica. Immunological Reviews, 240: 185-95.

[8] Kingston, D. G., Abdel-Kader, M., Zhou, B. N., Yang, S. W., Berger, J. M., van der Werff, H., Evans, R., Mittermeier, R., Malone, S., Famolare, L. (2000). Biodiversity conservation, economic development, and drug discovery in Suriname. Biologically Active Natural Products: Pharmaceuticals, 4: 3949.

[9] Ndjateu, F. S. T., Tsafack, R. B. N., Nganou, B. K., Awouafack, M. D., Wabo, H. K., Tene, M., Tane, P., Eloff, J. N. (2014). Antimicrobial and antioxidant activities of extracts and ten compounds from three Cameroonian medicinal plants: Dissotis perkinsiae (Melastomaceae), Adenocarpus mannii (Fabaceae) and Barteria fistulosa (Passifloraceae). South African Journal of Botany, 91: 37-42.

[10] Dos Santos, F. M., de Souza, M. G., Crotti, A. E. M., Martins. C. H. G., Ambrósio, S. R., Veneziani, R. C. S., e Silva, M. L. A., Cunha, W. R. (2012). Evaluation of antimicrobial activity of extracts of Tibouchina candolleana (Melastomataceae), isolated compounds and semi-synthetic derivatives against endodontic bacteria. Brazilian Journal of Microbiology, 43: 793-799.

[11] Nono, R. N., Barboni, L., Teponno, R. B., Quassinti, L., Bramucci, M., Vitali, L. A., Petrelli, D., Lupidi, G., Tapondjou, A. L. (2014). Antimicrobial, antioxidant, antiinflammatory activities and phytoconstituents of extracts from the roots of Dissotis thollonii Cogn. (Melastomataceae). South African Journal of Botany, 93: 19-26.

[12] Ngoudjou, T. D., Kodjio, N., Njateng, G. S. S., Fankam, A. G., Fokunang, C., Tala, D. S., Gatsing, D. (2017). In vitro antisalmonella and antioxidant effects of various extracts from leaves and stem of Tristemma mauritianum (Melastomataceae). Research Journal of Pharmaceutical, Biological and Chemical Sciences, 8: 1916-1924.

[13] Dongmo, M. R. C. (2009). Evaluation of antidermatophytic activity of methanol extracts and fractions of Acalypha manniana (Euphorbiaceae) and Tristemma hirtum (Melastomataceae). Master Thesis, Department of Biochemistry, University of Dschang, Dschang, Cameroon.

[14] Kuete, V., Wabo, G. F., Ngameni, B. (2007). Antimicrobial activity of the methanolic extract, fractions and compounds from the stem bark of Irvingia gabonensis (Ixonanthaceae). Journal of Ethnopharmacology, 114: 54-60.

[15] Fankam, A. G., Kuiate, J. R., Kuete, V. (2017). Antibacterial and antibiotic resistance modulatory activities of leaves and bark extracts of Recinodindron heudelotii (Euphorbiaceae) against multidrug-resistant Gram-negative bacteria. BMC Complementary and Alternative Medicine, 17: 168-173.

[16] Nguenang, S. G., Mbaveng, T. A., Fankam, G. A., Manekeng, T. H., Nayim, P., Wamba, E. N. B., Kuete, V. (2018). Tristemma hirtum and five other Cameroonian edible plants with weak or no antibacterial effects modulate the activities of antibiotics against Gramnegative multidrug-resistant phenotypes. The Scientific World Journal, 2018: 1-12. 
[17] Kenfack, N. J., Ponou, K. B., Kühlborn, J., Teponno, R. B., Nono, N. R., Fouedjou, T. R., Opatz, T., Park, J. H., Tapondjou, A. L. (2018). A new flavonol glycoside from Tristemma hirtum (Melastomataceae). Natural Product Sciences, 24: 1-6.

[18] Tagousop, N. C., Tamokou, J. D., Kengne, C. I., Ngnokam, D., Nazabadioko, L. (2018). Antimicrobial activities of saponins from Melanthera elliptica and their synergistic effects with antibiotics against pathogenic phenotypes. Chemistry Central Journal, 12: 97.

[19] Kuete, V., Ngameni, B., Fotso, S. C. C., Kengap, T. R., Tchaleu, N. B., Meyer, J. J. M. (2008). Antimicrobial activity of the crude extracts and compounds from Ficus chlamydocarpa and Ficus cordata (Moraceae). Journal of Ethnopharmacology, 120: 17-24.

[20] Bisoli, E., Garcez, W. S., Hamerski, L., Garcez, F. R. (2008). Bioactive pentacyclic triterpenes from the stems of Combretum laxum. Molecules, 13: 2717-2728.

[21] Bhangare, N. K., Pansare, T. A., Ghongane, B. B., Nesari, T. M. (2012). Screening for anti-inflammatory and anti-allergic activity of bharangi \{Clerodendrum serrratum (Linn.) Moon\} in animals. International Journal of Pharma and Bio Sciences, 3: $245-254$

[22] Serna, D. M., Martínez, J. H. I. (2015). Phenolics and polyphenolics from Melastomataceae species. Molecules, 20: 17818-17847.

[23] Zhang, Y., Wang, D., Yang, L., Zhou, D., Zhang, J. (2014). Purification and Characterization of Flavonoids from the Leaves of Zanthoxylum bungeanum and Correlation between Their Structure and Antioxidant Activity. PLoS One 9 (8): e105725.

[24] Iwashina, T., Kokubugata, G. (2012). Flavone and Flavonol Glycosides from the leaves of Triumfetta procumbents in Ryukyu Islands. Bulletin of National Museum of Nature and Science, 38: 63-67.

[25] Agrawal, P. K. (1992). NMR spectroscopy in structural elucidation of oligosaccharides and glycosides. Phytochemistry, 31: 3307-3330.

[26] Nzowa, K. L., Barboni, L., Teponno, R. B., Ricciutelli, M., Lupid, I. G., Quassinti, L., Bramucci, M., Tapondjou, A. L. (2010). Rheediinosides A and B, two antiproliferative and antioxidant triterpene saponins from Entada rheedii. Phytochemistry, 71: 254-261.

[27] Moreau, B., Lognay, G., Blecker, C., Destain, J., Gerbaux, P.,
Chéry, F., Rollin, P., Paquot, M., Marlier, M. (2007). Chromatographic, spectrometric and NMR characterization of a new set of glucuronic acid esters synthesized by Lipase. Biotechnologie, Agronomie, Societe et Environnement, 11: 917.

[28] Xiaojian, G., Xin, Z., Chao, Z., Huaguo, C., Yang, Z. (2013). Anti-inflamatory properties of quercetin-3-O- $\beta-D$ glucuronide-methyl ester from Polygonum perfoliatum in mice. International Journal of Pharmaceutics, 9: 533-537.

[29] Peng, Z. F., Strack, D., Baumert, A., Subramaniam, R., Goh, N. K., Chia, T. F., Tan, S. N., Chi, L. S. (2003). Antioxidant flavonoids from leaves of Polygonum hydropiper $\mathrm{L}$. Phytochemistry, 62: 219-22.

[30] Zhao, H., Shi, L., Cao, Q. J., Li, W., Wen, X., Zhao, Q. Y. (2010). A new triterpene saponin from Panax japonicus C. A. Meyer var major (Burk.) C. Y. Wu et K. M. Feng. Chinese Chemical Letters, 21: 1216-1218.

[31] Xie, G. B., Zhou, S. X., Lu, Y. N., Lei, L. D., \& Tu, P. F. (2009). Triterpenoid glycosides from the leaves of Ilex pernyi. Chemical and Pharmaceutical Bulletin, 57: 520-524.

[32] Chen, Y., Chiu, M. H., Gu, K., \& Li, Z. R. (2003). Cucurbitacin and triterpenoid glycosides from Hemsleya giganthy. Chinese Chemical Letters, 14: 475 - 478.

[33] Tamokou, J. D., Mbaveng, T. A., Kuete, V. (2017). Antimicrobial activities of African medicinal spices and vegetables. In: Medicinal spices and vegetables from Africa: therapeutic potential against metabolic inflammatory infectious and systemic diseases. 1st edition Elsevier, 8: 207237.

[34] Epifano, F., Genovese, S., Menghini, L., Curini, M. (2007). Chemistry and pharmacology of oxyprenylated secondary plant metabolites. Phytochemistry, 68: 939-953.

[35] Gatsing, D., Adoga, G. I. (2007). Antisalmonellal activity and phytochemical screening of the various parts of Cassia petersiana Bolle (Caesalpiniaceae). Research Journal of Microbiology, 2: 876-880.

[36] Garcia, A., Bocanegra-Garcia, V., Palma-Nicolas, J. P., Rivera, G. (2012). Recent advances in antitubercular natural products. European Journal of Medicinal Chemistry, 49: 1-23.

[37] Cowan, M. M. (1999). Plant products as antimicrobial agents. Clinical Microbiology Reviews, 12: 564-582.

[38] Botta, B., Vitali, A., Menendez, P., Misiti, D., Monache, D. (2005). Prenylated flavonoids: pharmacology and biotechnology. Current Medicinal Chemistry, 12: 717-739. 